\title{
Beyond Employability: Defamiliarizing Work-Integrated Learning with Community-Engaged Learning
}

\author{
Honor Brabazon, Jennifer Esmail, Reid Locklin, Ashley Stirling
}

\begin{abstract}
Within the context of an increasing interest in forms of work-integrated learning (WIL) among governments and institutions of higher education, this essay explores the relation between WIL and community-engaged learning (CEL) in order to argue that the structural and self-critique apparent in much CEL scholarship can serve as a model to WIL scholars and practitioners. CEL has undergone a rigorous process of self-examination in recent years, a process that has encouraged its advocates to think carefully about their core assumptions, appropriate learning objectives, and best practices in the field. In this way, we argue, whether or not CEL is classified as a form of WIL, it can serve to defamiliarize many of WIL's assumptions and to invite self-reflection in the field as a whole. In the first half of the essay, we provide background for the conversation, first in the Canadian context, and then in the broader scholarship of CEL. In the second half, we offer three case studies that illustrate both the distinctive characteristics of CEL and, in the last case, how these characteristics might strengthen the practice of traditional WIL.
\end{abstract}

KEYWords community-engaged learning, work-integrated learning, Neoliberalism, solidarity, reflection

For decades, universities have employed internships, co-ops, practical and field placements to prepare students for the demands of their future workplaces, particularly in the fields of education, health sciences, business, science, technology, engineering and mathematics (STEM), and other fields with a focus on pre-professional training. Such "work-integrated learning" (WIL) experiences are examples of the pedagogical practice whereby students learn through the integration of experiences in educational and workplace settings (Billett, 2009). WIL is facilitated for multiple reasons, including the goals of enhancing students' practical experience and "ease of transition" to the workplace following graduation. Many WIL experiences also aim to strengthen students' agency, sense of relevancy and connection with community, transferable skill development and intercultural competence. Aligned with the varied goals for WIL delivery, student success in these programs may be measured through varied means such as demonstrated professional competencies, in addition to their broader acquisition of such non-tangibles as practices of self-management and awareness of the labour market and community needs, and what one researcher has labelled their "pre-professional identity" (Jackson, 2016; 2017).

As government discourse increasingly emphasizes strategically connecting higher education 
with industry and community to better facilitate alignment of educational preparation with societal needs, government actors are taking notice of the practice of work-integrated learning and are keen to advance this pedagogical approach in higher education. To cite just one example from our local context, in 2015, the Ontario provincial government appointed five academic, community and industry leaders to create the Premier's Highly Skilled Workforce Expert panel, with a mandate to develop a strategy to help the province's workforce adapt to the demands of a technology-driven knowledge economy. In June 2016, the Panel released its report, recommending that Ontario provide students with increased opportunities for skill development by ensuring that "every student has at least one experiential learning opportunity by the time they graduate from post-secondary education" (p. 27). Within this context, the Ministry of Advanced Education and Skills Development (MAESD), subsequently defined the term "experiential education" as authentic workplace experience connected to the student's field of study that is recognized and assessed by the post-secondary institution (MAESD, 2017). At the federal level, the Business and Higher Education Roundtable also recently recommended that " $100 \%$ of Canadian post-secondary students benefit from some form of work-integrated learning prior to graduation” (BHER, 2016, p. 9). With funding at both federal and provincial levels being directed to advancements in work-integrated learning, attention to this student practice continues to grow as a desideratum for higher education in the early twenty-first century.

Historically, alongside co-op and internship models of pre-professional education, faculty in the social sciences and humanities in particular have employed curricular service-learning and/or community-engaged learning methods, often to reinforce course content but equally often to interrogate or radically disrupt it through meaningful and reciprocal engagement with community (see Butin, 2005a, 2005b). In this essay, we use the term "communityengaged learning" (CEL) to refer to a range of community-university engagements that aim to support both community priorities and student learning, including the more specific pedagogical approach known as "service-learning" (SL), which Jacoby (2014) defines as "a form of experiential education in which students engage in activities that address human and community needs, together with structured opportunities for reflection designed to achieve desired learning outcomes" (p. 1-2). We will typically use the term CEL because of its expansiveness and its shift away from the discourse of "service" in favour of "engagement," but will use SL when talking about literature in the SL field. Sometimes CEL or SL is classified as a form of WIL (Sattler, 2011). At other times, CEL or SL is positioned as alternatives to or even critiques of WIL. Occasionally, as in a recent white paper on Rethinking Higher Education Curricula by faculty at the University of Toronto (2017), CEL and WIL are treated together as distinct, complementary and overlapping species of some shared genus, specified as "Integrated Learning Experiences."

In this essay, we offer an exploration of the relation between WIL and CEL. Recognizing others' assertions of CEL as fundamentally different from WIL, distinguished by its intent to ensure equal focus on both the "service" being provided and the learning that is occurring (Furco, 2010), we attempt to unsettle any simplistic identification or conflation of the two 
learning strategies. At the same time, we also explore the potential impact of CEL on WIL when they are considered in constructive relation. We observe that CEL has undergone a rigorous process of self-examination and self-critique in recent years, a process that has encouraged its advocates to think carefully about their core assumptions, appropriate learning objectives and best practices in the field. The fruits of this rigorous self-reflection may, we suggest, represent a useful resource not only for CEL, but also for the broader array of teaching methods and practices classified as WIL. In this way, we argue, if and regardless of whether or not CEL is classified as a form of WIL, it can serve to defamiliarize the practice of WIL, to challenge some of its leading assumptions about the role and function of integrated learning experiences, and thus to invite self-reflection in the field as a whole. Here we offer a few insights, informed by our teaching and engagement with CEL, along with their potential consequences for rethinking WIL. In the first half of the essay, we provide background for the conversation, first in the Canadian context and then in the broader scholarship of CEL. In the second half, we offer three case studies that illustrate both the distinctive characteristics of CEL and, in the last case, how these characteristics might strengthen the practice of traditional WIL.

\section{Work-Integrated Learning: The Conversation in Canada}

While there are several working definitions of WIL (BHER, 2016; Billett, 2009; Patrick, Peach \& Pocknee, 2009), the main definitional criteria include participation in workplace activities, connection with academic curricula, and the reflective integration of learning in academic and workplace contexts. The use of the term "work" stems from the foundation of the field in cooperative education and professional placements, where the experience has been historically associated with student employment or tied to professional competency development of the particular workplace settings. However, it may also be interpreted broadly as referring to experience with community populations, organizations and/or industry outside the academic institution. "Workplace" activities range from the participation of students in the day-to-day activities of the workplace to community-partnered student projects such as applied research projects, project-based consulting or innovation/entrepreneurial developments (Stirling et al., 2016).

For an activity to be considered WIL, it is expected that the experience is "authentic" and "meaningful." Authenticity is measured by the alignment of the experience to real-world tasks and its proximity to current workplace settings (Bosco \& Ferns, 2014). The meaningfulness of the activity is tied to the criteria for connection to the student's field of study, the quality of the learning experience, and the engaged contribution of the student within the workplace (Stirling et al., 2016). WIL provides students with the opportunity to apply what they have learned in class in a workplace setting, and in turn, to enhance classroom learning with lessons learned in the workplace. In WIL, learning outcomes may be academic and/or career-related. For example, they can include discipline-specific competencies, technological competencies, learning competencies, transferable competencies, or competencies of employability (U of T, 2017). While WIL is described as a pedagogical approach itself, it is often considered a practice 
and is grounded in other learning theories in an attempt to enrich the educational quality of the experience. Experiential learning theory (Kolb, 1984), activity theory (Vygotsky, 1978), situativity theory (Dunning \& Artino, 2011), situated learning theory (Anderson, Reder \& Simon, 1996), and workplace pedagogy (Billett, 1996; 2002) are all theoretical frameworks that may be used to ground the pedagogical delivery and quality enhancement of WIL.

WIL is typically used as an umbrella term to describe different examples of practice outside the traditional classroom setting, and there is increasing pressure for a broad range of activities to be included in WIL typologies for higher education tracking and measurement purposes. The Higher Education Quality Council of Ontario's typology of WIL includes seven types of opportunities - apprenticeships, field placements, mandatory professional practice, coops, internships, applied research projects, and service-learning (Sattler, 2011). Building on this, emerging typologies of WIL published provincially, federally, and across institutional contexts (sometimes referred to as experiential learning typologies) increasingly encompass CEL and/or SL in recognition of the inherent element of community-engagement that they share. However, for reasons we will discuss in the next section, it is not uncommon for CEL practitioners to eschew the "WIL" moniker and reject the whole enterprise.

\section{Critical Community-Engaged Learning: Four Distinctive Characteristics}

CEL sits in complex relation to what some consider WIL's prioritization of a market-driven logic for education. Historically, higher education has traditionally placed a high value on volunteerism and community engagement as an element of character formation. Influenced in part by the educational theory of John Dewey (1938), educators in the 1960s and 1970s developed SL as a distinctive pedagogical tool that placed special emphasis on the role of experience and reflection in the educational process, and this term remains ubiquitous in the scholarly literature. In the past decade, Community-Based and Community-Engaged Learning (CBL and CEL) have been proposed as terms that more fully reflect the values of reciprocity and critical engagement that are central to this approach. Given CEL's emphasis on community engagement over employment preparation, and on the communal over the individual, CEL practitioners often resist the WIL label as a description of their pedagogical approach. Indeed, many may be motivated to use the CEL approach in part because of their opposition to the perceived neoliberal frameworks of WIL and, more broadly, the commodification of contemporary higher education.

Yet, CEL itself is also often heavily imbricated in the neoliberal project of "academic capitalism," to borrow Slaughter and Rhoades's (2004) term. Whether or not CEL is explicitly considered a form of WIL, there are CEL/SL practitioners and scholars who approach their work from a charitable model of service provision that emphasizes individual service over structural critique and solidarity, or who prioritize career benefits to students over community impact. In her survey of SL literature, to differentiate between what she identifies as "traditional" and "critical" SL, Mitchell (2008) describes the former as incorporating "service without attention to systems of inequality," stressing benefits to students over community impact, and the latter as "unapologetic in its aim to dismantle structures of injustice" (p. 50). 
Out of the recognition of the ways that CEL/SL contributes to, and benefits from, neoliberal models, there has emerged a well-honed suspicion in a vibrant strand of CEL theory and practice, referred to by some as "Critical SL" or "Critical CEL," that relentlessly engages in a critical exercise: that of questioning its own existence and its own contributions to the neoliberal paradigm. We point to this important body of scholarship and practice because it informs our work and because we have not encountered the same emphasis on selfcritique, nor the same valuing of self-consciousness about objectives, partnerships, student contributions and the purpose of higher education, in the literature and practice of WIL more broadly. We argue that the scholarship that has emerged out of Critical CEL can serve to helpfully illuminate areas of tension in WIL initiatives that may lead to improvements for all partners involved. Furthermore, we argue that this critical CEL scholarship can serve as a model for the next wave of WIL scholarship which will, we hope, engage in similar selfexamination and self-critique.

From our review of the literature, we recommend the following characteristics of CEL, and Critical CEL in particular, for special attention concerning WIL:

\section{Community-engaged learning is self-critical}

Some of the most engaged theorists of CEL/SL are themselves its most strident critics. Randy Stoecker, for instance, has a long record of asking whether CEL/SL is a valuable enterprise given that, in his assessment, it benefits universities and students far more than community partners. Stoecker (2016) explains that his scholarship aims to,

figure out a service learning practice that doesn't stop at totaling hours from time sheets, 'building relationships,' and providing a tick box for the university's community engagement Carnegie classification. [He] want[s] a practice that becomes part of real social change- that helps to end conditions of oppression, exploitation and exclusion in society. (p.4).

Mitchell (2008) also highlights how a supposedly progressive form of experiential learning ends up replicating problematic hierarchies of power when it emphasizes student development outcomes over social change. She has expanded upon notions of "critical SL" to offer a rigorous critique of "traditional" approaches to SL: for Mitchell (2008), practitioners of CEL are ethically obligated to employ a critical approach to SL which employs "a social change orientation, work $[\mathrm{s}]$ to redistribute power and develop[s] authentic relationships (p. 62)." Both Stoecker and Mitchell share concerns that the objectives and outcomes of CEL can reinforce the power of the privileged institution of the University and the marginalization of community members by simply understanding "community" as a site in which to educate students apolitically, without reference to the priorities of the community itself or broader social change.

CEL scholars and practitioners have also increasingly articulated specific concerns about how CEL has been co-opted by larger forces at work in higher education like academic 
capitalism and neoliberalism (Brackmann, 2015; Clifford, 2017; Kliewer, 2013; Mitchell, 2008; Morton \& Bergbauer, 2015; Raddon \& Harrison, 2015). The incorporation of CEL into WILrelated discourses, which frame CEL as a way for students to gain employment experience, can be dismaying for those who engage in CEL pedagogy precisely because they want to displace notions of students as both consumers and products. They do this by engaging students in critical reflection and experiential learning related to structural inequities. As Clifford explains, "these trends to prioritize skills, credentials, products, and personal agency call into question the motivations, expectations, and practices by students in SL that are tied to social justice" (p. 8). According to Raddon and Harrison (2015), however, scholars who situate the incorporation of CEL in a broader neoliberal emphasis on market imperatives in higher education may not be going far enough. Raddon and Harrison (2015) argue instead, that the emergence of CEL in Canada is correlated directly to neoliberal changes to education more broadly: "servicelearning is clearly fashioned in and by the neo-liberal turn of recent decades" (p. 137). As a result, we argue that critical CEL scholarship can model to WIL scholarship a two-fold self-consciousness and self-criticism. Much of the literature interrogates the value of CEL pedagogy itself while simultaneously locating how tensions in the pedagogy and practice may be tied to broader structural forces.

\section{Community-engaged learning engages cognitive dissonance}

Another key feature of critical CEL lies in its potential for re-framing or even disrupting the entire academic enterprise as it is traditionally practiced. As Howard (1998) has noted, the pedagogy can be considered "counternormative" in the ways that it interrogates what (and whose) knowledge counts, how it should be "delivered," and to what end (see also Clayton \& Ash, 2004). Other scholars have also emphasized how some community-engaged learning practice allows for a shift from a more positivist approach to education and knowledge towards a model where knowledge is co-produced through the integration of classroom-based and community-based experience and the sharing of experience among students, faculty and community partners. In Butin's (2005a) words, "service-learning challenges our static notions of teaching and learning, decenters our claim to the labels of 'students' and 'teachers,' and exposes and explores the linkages between power, knowledge, and identity" (p. vii-viii). Such a challenge is especially pressing in the conceptualizations of SL that Butin terms "postmodern" or "anti-foundationalist." Unlike many models of WIL, which might frame the placement as essential for students to gain key workplace knowledge, skills, and abilities and to apply what they already know to a workplace situation, critical CEL scholars ask students to do something more challenging: to reconsider how they understand the concepts of knowledge, skills, and abilities altogether.

\section{Community-engaged learning focuses on reciprocity and its relationship with community partners}

CEL might also be distinguished from other forms of experiential learning by its focus on relationships between students, university faculty and staff, and community partners. This 
emphasis on the relational, and, more broadly, on process over product, is a crucial feature of many CEL approaches. The dominant term that encapsulates this notion in the field is "reciprocity," which has been defined by Jacoby (2014) as,

relating to the community in a spirit of partnership, [and] viewing the institution and the community in terms of both assets and needs... Reciprocity implies that the community is not a learning laboratory and that service-learning should be designed with the community to meet needs identified by the community" (pp. 3-4).

Every leading CEL theorist, and especially those engaged in more critical approaches to CEL, emphasizes the essentiality of reciprocity to CEL (Bringle \& Hatcher; 1995; Bringle \& Clayton, 2012; Butin, 2010; Furco, 1996; Jacoby, 2014; Mitchell, 2008). Indeed, for some, "reciprocity" is considered a defining characteristic of the pedagogy. In Furco's (1996) influential diagram of service-learning as a "balanced" approach, the engagement must be designed to equalize the "service" provided by the student with the "learning" gained by the student. Without this balance, according to Furco, the community engagement tips into either pure volunteerism, on the one side, or a form of work-integrated learning, such as an internship, on the other.

The very concept of "reciprocity," however, has come into question more recently in critical CEL scholarship because of the diverse ways that the term is deployed (for instance in its inclusion of everything from co-designed research to a quid-pro-quo transaction); skepticism that the concept truly reckons with the power dynamics inherent in communityuniversity engagement; and concerns that it does not demand enough from university faculty, staff and students (Clifford, 2017; Dostilio et al., 2012; Hammersley, 2013; Hammersley, 2017; Jameson, Clayton, \& Jaeger, 2010; Mitchell, 2008; Morton \& Bergbauer, 2015; Stanlick \& Sell, 2016; Stoecker, 2016). Critics are increasingly advocating for an even more relational mode of engaging in CEL. Clifford (2017), for instance, suggests shifting from transactions of "reciprocity" to relations of "solidarity" in CEL practice in order to "clearly define relationship building [with communities and community organizations] as the backbone of SL" (p. 13). Mitchell (2008) also emphasizes "developing authentic relationships," based on solidarity, a concept which "extends beyond the service relationship to a broader commitment to social justice; it reflects what is possible once the service-learning course ends" (p. 61).

An element of this critical re-imagining of relations with community partners is a concomitant re-imagining of the role of the student in the partnership. That is, one consequence of focusing on relations and process, over reciprocity and product, is a de-centering of student contributions. Much of the recent theory in the field takes up the complexity of how to understand what students are both providing and acquiring in CEL. Critics have expressed concern about the potential for CEL engagements to enable a sense of unearned, and problematic, "charitableness," in students (Heldman, 2011; Mitchell, 2008; Pompa, 2002). One of Pompa's (2002) key critiques of SL, for instance, is that it "can unwittingly become an exercise in patronization. In a society replete with hierarchical structures and patriarchal 
philosophies, service-learning's potential danger is for it to become the very thing it seeks to eschew" (p. 68). For some, addressing this potential danger requires a very careful framing of, and preparation for, student contributions to CEL. Mitchell (2008) advocates attention in class to power imbalances between students and community members; Heldman (2011) describes her attempts to address student privilege through pedagogical interventions that are primarily tied to reflective assignments and activities; and Stanlick \& Sell (2016) invite CEL practitioners to "name and avoid the superhero mentality and to focus instead on connecting and sustaining, with the goal of collective empowerment at the forefront" (p. 80; italics in original). Where WIL initiatives might emphasize student knowledge and skills — both in what students contribute and what students gain — critical CEL practice increasingly attempts to complicate and de-center the student role and to ask students to reckon with that complexity within a broader discourse that interrogates the community-university relationship.

\section{Community-engaged learning places special emphasis on the reflective process}

As is the case with the concept of reciprocity, many CEL scholars would consider the incorporation of student reflection as a definitional feature of CEL (Bringle \& Hatcher, 1995; Hatcher \& Bringle, 1997; Jacoby, 2015). Hatcher and Bringle (1997) describe reflection as "the intentional consideration of an experience in light of particular learning objectives" (p. 153). This emphasis on reflection emerges in part from the field's indebtedness to theorists of experiential learning, including Dewey and Kolb, who stress that reflection on experience, rather than experience alone, is necessary for learning. Much of the scholarship frames reflection as the space where students can learn from their experiences in the community, in part by connecting those experiences with course content (Ash, Clayton \& Atkinson, 2005; Bringle \& Hatcher, 1995; Eyler, 2002; Eyler \& Giles, 1999; Jacoby, 2015; Mitchell, 2008).

While many forms of experiential WIL also typically incorporate some form of reflection, CEL often places particular emphasis on the reflective process, or on what many describe as "critical reflection." That is, in many CEL courses, the reflective process is itself subject to meta-reflection as are the other processes we have already identified as key to the field: the critical engagement with the pedagogy and practice, the disruption to traditional understandings of education, the building of relationships with community partners and the troubling of the student role in a CEL course. For theorists like Eyler (2002), Mitchell (2008) and Jacoby (2015), reflective activities and assignments are essential for enabling students to learn, in particular, about the structural causes for social inequities that they might encounter in their community engagement. As Jacoby (2015) puts it, "critical reflection raises critical questions which challenge us to consider multiple perspectives and to recognize complexity in a situation or issue that may initially seem to be straightforward" (p. 27). What might be said to distinguish reflection in CEL from reflection in WIL, then, is how it is often used in CEL not simply as a way for students to articulate what they have learned but also as a vehicle for critically considering the complexities of the very learning process that students are undertaking.

Engaged Scholar Journal: Community-Engaged Research, Teaching, and Learning 


\section{Engaging Communities: Three Case Studies}

Thus far in this essay, we have spoken about community-engaged learning entirely in the abstract, as it emerges in the scholarly literature, and we have suggested four defining characteristics. Some of these characteristics and practices — notably, some forms of reflection — are already recognized in the wider literature on WIL. However, they have assumed distinctive importance and critical function in the context of CEL. We propose that whether or not CEL is classified as a form of WIL, it can serve to defamiliarize many of WIL's assumptions and to invite selfreflection in the field as a whole through application of CEL's reflexive practice of self-critique; its engagement of cognitive dissonance; its emphasis on reciprocity and relationship; and its focus on the reflective process. In this section of the essay, we turn from these principles to their concrete application in two courses that we have had occasion to teach: two case studies in CEL - one from the social sciences, and the other from the humanities. We offer these not as impossibly perfect ideals, but precisely as "typical" examples: ordinary courses, which both succeeded and failed in their learning objectives, but which nevertheless well illustrate the distinguishing characteristics of CEL. The third and final case study, based on a graduate placement course in Kinesiology, offers an initial attempt to incorporate wisdom from CEL into a more traditional, vocationally-oriented WIL context.

\section{Case Study 1: "Neighbourhoods and Crime"}

While CEL is eminently compatible with the neoliberal paradigm of post-secondary education, it also offers opportunities to teach students about neoliberalism and to think critically about how neoliberalism is reflected and reproduced — both in the organizations they are placed at and in the very notion of CEL. These opportunities will be discussed using the course "Neighbourhoods and Crime," which one of us (Brabazon) developed into a CEL course in 2016. The course is offered as a 12-week seminar for fourth-year undergraduate students in the Criminology and Sociolegal Studies program at the University of Toronto. Students in the course sign up for a 25-hour volunteer placement with a community organization in the Greater Toronto Area. These are typically organizations that provide targeted services such as job search assistance for the unemployed, group support for recent migrants, or multi-media programs for youth in stigmatized neighbourhoods. Students keep a log of their activities and reflections on their placements, and they integrate these reflections into their course papers. They also share their reflections with the class both through an oral presentation and in their interventions in class discussions.

The readings and class discussions engage students in a critical examination of how and why certain neighbourhoods are associated with criminality while others are not. Course topics include moral panics; segregation; gentrification; the differential treatment of crimes of the wealthy versus those of the poor; the politics of attempts to associate certain types of neighbourhood with crime; and the limitations of the various solutions to the problem of 'bad neighbourhoods' that are commonly proposed. Throughout the course, emphasis is placed on which questions are asked about in relation to stigmatized neighbourhoods and which questions are ignored, and from whose perspectives these questions are asked. In their analysis 
of readings and field placements, students are encouraged to consider how neighbourhoods are perceived and evaluated from within and from without. Historical changes and recurring themes in the association of certain neighbourhoods with crime are considered throughout the course amid discussion of how shifting conceptions of society, of the individual, of relations between individuals, and of social institutions in the neoliberal period are brought to bear on these themes.

This critical and contextual social science approach provides a clear entry point for discussions of neoliberalism, and the course invites the students themselves to reflect upon how the neoliberal paradigm is reflected and reproduced in the social processes discussed in class, in the social context in which their placement organizations operate, and in the very notion of CEL. For instance, the placements provide an opportunity to observe the shifting conception of the state and the provision of social services in the neoliberal period that is discussed in the course readings. Students learn that, as government social spending has been cut back, NGOs - where many students have their placements — are increasingly providing social services to pick up the slack (Sinha, 2005; Perkins, 2009). Students are encouraged to use their placements to reflect upon the advantages and limitations of providing these services through NGOs versus government programs or alternative means, including the extent of change that is possible - for instance, individual vs. structural change.

Students consider how placements at NGOs can reflect and reinforce the culture of charity and voluntarism that has been celebrated in the neoliberal period (Perkins, 2009; Williams et al., 2012), which is rooted in the notion that the provision of community services is an act of generosity toward the less fortunate rather than a collective responsibility that bears far-reaching social benefits. Within the context of services provided by NGOs, students use examples from their placements to explore the differences between top-down and horizontal organizational approaches (Carniol, 1992) and to distinguish between the charity model, in which benefits are generously donated to 'less fortunate' communities, and the solidarity model, in which those communities' initiatives and campaigns are supported and amplified by the work of the NGO (Toomey, 2009).

Similarly, the course provides an opportunity for students to discuss CEL itself in the context of the shifting conception of the university from a public good toward the neoliberal notion of post-secondary education as a commodity that students purchase to increase their value as products on the labour market - their 'human capital' (Giroux, 2014). In the neoliberal economy, workers increasingly are expected to be trained and 'work-ready' before they are hired, which means that the cost and responsibility for job-training fall on individual workers rather than on employers (Lakes, 2011). Students in the course are encouraged to examine their motivations for participating in a CEL course in this context. They reflect on the pressure they feel to acquire 'workplace skills' and on what alternative benefits might be gained from this experience. Students also reflect on how volunteer placements can normalize the provision of social services through unpaid labour. This has created opportunities for discussion of how volunteering to do work otherwise done by paid employees can devalue the work of skilled community service providers, as well as how this can legitimize unpaid

Engaged Scholar Journal: Community-Engaged Research, Teaching, and Learning 
internships and other 'work experiences' (Bach, 2012), which the students fear they will face for years after their graduation.

While many of the dynamics that constitute neoliberalism are taught to undergraduate students in broad strokes, the placements in this course provide students with real-life examples of how these dynamics are implemented, negotiated, and challenged in local contexts, including the variation, contradiction, and contestation that can occur in the process (Brabazon, 2017). This facilitates a robust understanding of the complexity not just of neoliberalism but of social systems and power relations more generally.

The students relate their placements to the patterns and theories discussed in class in a presentation and an essay submitted at the end of the course. They also submit the log they keep of their reflections on the placement throughout the course. In their logs, they have raised complex questions about their own role at the placement and about how to understand how their placement organization might be beneficial while also contributing to these neoliberal dynamics.

Their logs also illustrate how their perspectives have changed throughout the course. In the critical CEL tradition of questioning processes of knowledge production, students read researchers' accounts of stigmatized neighbourhoods (Lewis, 1975; Stack, 1970; James, 2010) and discuss the authors' methodologies and how the authors' positionality in relation to the neighbourhoods they examine might affect their approach and conclusions. Students are encouraged to consider their placement as their own participant observation field research and to be aware of how their positionality gives them 'insider' and 'outsider' perspectives. They are encouraged to note their preconceptions about the neighbourhood their placement is in; how they first perceive that neighbourhood, including what they see as signifiers of danger or safety and why; and how those they meet through the placement see the neighbourhood. They are prompted to note how their 'knowledge' of that neighbourhood changes over time, and they are encouraged to relate their reflections to class discussions of the processes of othering, essentializing, and racializing that shape the limited 'knowledge' about these neighbourhoods that underpins much of the policy directed at them (Katz, 1993; Wacquant, 2001).

In response to Stoecker's and Mitchell's respective concerns that service-learning often involves using communities to benefit students without educating them about the priorities of those communities, students in this course are encouraged to learn as much as possible about the priorities of their placement organization and the communities it is part of, as well as the struggles those communities have won and the barriers they still face. Nevertheless, there is no doubt that the placements still benefit the students and the university more than the placement organizations themselves. The course still operates within the neoliberal paradigm of the university and of CEL, providing students with 'work experience' for the job market. However, within this framework, the course offers an example of how CEL can also create an opportunity for critical reflection on this paradigm and for decentring it.

\section{Case Study 2: "International Development, Justice and Human Dignity"}

Arguably, the practice of CEL and its specialized scholarship of teaching and learning are 
associated most closely with the social sciences. This close association informs both its tendency to be positioned in terms of a neoliberal production of "market-ready" labour and the interpretive tools it offers for resistance. Both tendencies are well illustrated in the discussion of the course "Neighbourhoods and Crime," above, in which the course content directly engages questions of stigmatization, students' subject positions at their placements, and the neoliberal economy.

In the context of the humanities, both the rhetoric of commodification and the particular concerns raised by community engagement shift in subtle ways. These will be illustrated regarding the international CEL course, "International Development, Justice and Human Dignity" hereafter referred to by its abbreviated title, IDJustice. This course, which one of us (Locklin) taught for over a decade as part of the undergraduate Christianity and Culture program at the University of Toronto, consisted of a one-term seminar on development theory, philosophical anthropology and critical theory and a one-term, 8- to 13-week placement with a grassroots community partner in Latin America, Africa, Eastern Europe, or South or Southeast Asia, or in underserved communities in Canada. In the overwhelming majority of cases, students lived in the communities they served, usually in family homes but also in other forms of intentional community. Students completed regular reflections on readings and placement experiences, and the final course requirement was a major integration paper. The course was offered as one of several third-year offerings in a thematic cluster of courses related to "Christianity and Society," but it included students from a wide range of different subject areas who were at various points in their undergraduate careers.

Earlier in this essay, we discussed criticisms of the "charity model" of community engagement, as well as the implication of many practices of CEL with highly inequitable relations between university and community partners. To some extent, the IDJustice program was designed with this criticism in mind. First of all, the program emerged initially out of a partnership with an NGO associated with the international L'Arche movement, founded by the Canadian philosopher Jean Vanier (see Locklin, 2010). Core principles of this movement include solidarity and mutual vulnerability between those who are privileged and those who have been marginalized by dominant structures — in particular, in the context of L'Arche, persons with intellectual disabilities. Some students' international placements involved work in L'Arche communities; most students worked in educational settings, in cooperative agriculture, or in peacemaking. Nevertheless, for every student at every stage of the program, from recruitment to the final post-placement meeting, the instructor and several assigned theorists (including Vanier) critiqued instrumentalist conceptions of the placement communities, in favour of an ethic of engaged witnessing and creative accompaniment. That is, students received repeated reminders that they were being sent to live and work in solidarity with local change-agents, not for them to "make a difference" or to imagine themselves as the primary agents of change.

Secondly, as a course in the humanities, the IDJustice program was designed not to serve what Butin (2003) has called "technical" or "political" learning outcomes, but rather to disrupt student preconceptions, to foster "empathetic accountability" across boundaries of difference, and to encourage more sophisticated patterns of reasoning (Locklin \& Posman, 
2016). In Butin's terms, the community engagement embodied a "poststructural" or "antifoundationalist" approach (Butin, 2005b); in engaging students, instructional staff often spoke in terms of perspective transformation (Mezirow, 1991; Mezirow, 2000; Kiely, 2004; Kiely, 2005a; Kiely, 2005b). During the placement, each student was paired with a reflection partner (usually the course instructor or another suitable academic mentor). The role of this reflection partner was to receive student reflections, to provide support where needed, and to press the student to relate their experiences to theory in ever more complex and creative ways. Importantly, these reflections also became sites for challenging the stereotypes that inevitably arose along the way.

Finally, over the decade that IDJustice was offered, the instructional team and Canadian collaborators worked assiduously to maintain consistent and transparent relationships with international partners, and to position host communities as co-learners and co-creators of the program (see MacDonald \& Vorstermans, 2015). Prior to their international immersion, for example, students completed several workshops, including a presentation on their prospective partners' experiences and perceptions of students completing placements in their communities. Partners were encouraged to disclose to students their motives for participating in the program - which, more often than not, had less to do with the students' professional expertise and more to do with the partners' own long-term interest in shaping perceptions of their organizations in their local contexts and in international power centres like Canada. Insofar as possible, students in the program were encouraged to regard themselves reflexively, as objects of critical reflection, as well as reflecting subjects.

Despite all of these strategies, intended to disrupt neoliberal structures and instrumentalist approaches to the educational project, IDJustice was far from immune to a culture of commodification. Critics of study abroad, including international CEL, have drawn attention to the ways it can reinforce neo-colonialist structures of dependence and reify the privilege of global mobility (e.g. Zemach-Bersin, 2007; Larsen, 2015; Derris \& Runions, 2016). These dynamics were clearly at play in the IDJustice program. Recruitment of student participants emphasized the potential for transformative experience: potential applicants were encouraged, in the language of our NGO partner, to "discover the world with the eyes of the heart," and advertising materials depicted Canadian students — often though not always white beaming while holding children, milking cattle, or harvesting crops with members of local communities (who were almost invariably persons of colour). College publications celebrated students' willingness to make themselves vulnerable in their placement communities, and highlighted the ways their views of the world were transformed (Locklin, 2010). The primary commodity in this case was the experience and the promise of transformation, rather than professional experience and the development of contact networks. This did not, of course, prevent students from highlighting this unique experience on their CVs.

What distinguished the IDJustice program, precisely as a CEL course, was not that it had somehow managed to avoid its implication in unjust global structures. What distinguished it was a course curriculum that encouraged students to interrogate these structures. Not all students emerged from their placements with a transformed perspective on life; some wrote 
final integration papers that offered sharp criticisms of the philosophy of Jean Vanier or the structure of the course, informed by their experience and the relationships they formed therein. Such processes of critical reflection often continued well after the conclusion of the course, based on subsequent correspondence with the course instructor and other animators of the program. When it succeeded in its course objectives - like all courses, it sometimes failed — the IDJustice program provided its participants with a kind of WIL, albeit one that valued failure as much as success and placed its emphasis squarely on the question of relationship. More than this, at least ideally, it equipped students with critical tools and reflective practices to pose questions of their experience and ever more clearly to articulate and interrogate their own motives, meanings, and values.

\section{Case Study 3: Master of Professional Kinesiology "Placement 1"}

Our first two case studies demonstrated key elements of Critical CEL. Our third and final case study demonstrates one way that these critical tools and reflective practices might fruitfully incorporate into a WIL course. While not structured deliberately as CEL, the characteristics of CEL identified above have inspired the development and delivery of a placement course by one of us (Stirling) within the Master of Professional Kinesiology (MPK) program at the University of Toronto. This placement course was designed to facilitate practice opportunities that enhance student learning and hands-on experience, as well as to provide meaningful exercise and physical activity opportunities for underserved community members. Inspired by Mitchell's (2008) critical perspective on the need to emphasize "solidarity" and partnership with community while addressing broader social justice needs, the impetus for this course galvanized from a personal relationship with a local centre providing programs and services for persons with intellectual and developmental disabilities. More specifically, the idea for the course practice stemmed from a shared passion with other families and clinical directors at the centre for improving access and opportunities for movement programming for underserved children and youth at the centre and within the surrounding community.

Distinct from traditional WIL placement models, where students are paired with a mentor in a community organization and given an opportunity to observe, assist, and practice as appropriate in a selected career path, this course's novel physical activity program was developed for student delivery, in partnership with community organizations. To create capacity for 40 students to gain meaningful practical experience within their field of study, the initial partnership formed with this centre fuelled a broader consultation leading to the identification of four communities of focus based on community-identified priorities and limited, or lack of, opportunity to access the services the MPK students could provide. Ultimately, the placement course's populations of focus included people with psychiatric diagnoses, community members living with chronic disease, concussed athletes, and children and youth with developmental disabilities. This case study will focus on the portion of the course tied to the practice with children, as it was the foundational community partnership driving the commitment to reciprocity across all course practice.

In partnership with the community centre and with a local public school, a physical

Engaged Scholar Journal: Community-Engaged Research, Teaching, and Learning 
activity program, called S.M.I.L.E. (Sensory Motor Instructional Leadership Experience), was developed. An innovative 12 -week physical activity program built loosely upon a pre-existing student leadership program at Acadia University, S.M.I.L.E. is intended to provide unique opportunities to participate in individualized physical activity programming for children and youth with varying ability levels. Each child is paired one-to-one with an MPK student to participate in adapted programming for physical literacy and fundamental movement skill development. Through delivery of the program, MPK students assess the movement skill development of the children, facilitate weekly exercise programming that is adapted to the specific level, interests, and overarching goals of each child, and develop mid-session and final reports for the families, teachers and clinicians at the centre highlighting the success of the children in the program.

This placement runs alongside the students' other academic courses to more strategically link the students' practice experiences with the broader MPK curriculum at multiple points of intersection with other courses. In particular, following each session students are required to document clinical notes and personal reflections on the practice. In class tutorials, the students are then challenged to think more critically about their experience in S.M.I.L.E. and are asked to reflect on how they are learning with and from the children in the program. In traditional service- and problem-based approaches to the prescription of exercise, the kinesiologist may see him or herself as an expert swooping in to solve an issue or assist a person in need. In this program, through critical dialogue, the students work from a strength-based approach and critique the philosophical underpinnings of the strength-based and the more traditional problem-based approaches to care. Importantly, using Howard's (1998) phrasing, the students also engage in a "counter normalizing" exercise where they come to question how popular movement assessment tools are developed. Specifically, they critically question how drawing samples from specific populations and contexts can influence the utility of such tools in diverse populations, as well as our perceptions of normalcy in kinesiology practice.

The ethics and morality of facilitating such a program and introducing families to opportunities that are not available to the children once the program is completed is frequently discussed. Influenced by engagement in the S.M.I.L.E. program and discussions of the need for social change, some students have taken action in their own practice since graduation. A few students have gone on to build new programs with this population in the community, sometimes as a targeted program and in other examples through the infusion of inclusivity and adaptive provisions to existing able-bodied children's programming, reflecting steps in the right direction towards more sustainable physical activity opportunities for this community.

While it is an open question whether this placement course would satisfy all of the requirements of critical CEL, it nevertheless reflects a number of CEL's core concerns, particularly insofar as it has been carefully designed to question the value of the practice the placement affords, and who is truly benefitting from the experience provided. It reflects deep learning from CEL colleagues and their concerns about framing CEL courses within the broader WIL narrative predominantly focused on workplace readiness. Such conversations provide important opportunities to re-think how and why we deliver practice in a professional 
graduate program and to gain a renewed appreciation for the potential value of engagement with community well beyond the inherent professional skill development.

\section{What is Engagement For? An Opportunity for Community-engaged learning to Influence the Traditions of Work-Integrated Learning}

Our suggestion in this essay is not that CEL practitioners embrace the market logic that inheres in many WIL initiatives; indeed, it is almost precisely the opposite. CEL (and SL as its most pervasive pedagogical practice) has a deep history of both pedagogical innovation and self-reflexive critique, which seek to resist the commodification of our educational institutions and to interrogate the relationships of those institutions with vital community partners. It is this self-reflexive critique of aims and impact, and the practices that follow from it, that CEL can offer to emerging discourses of WIL.

At least arguably, the broader literature and practice of WIL do not reveal the same emphasis on self-critique, the same valuing of self-consciousness about objectives, partnerships, student contributions, nor the purpose of higher education that we find in the scholarship on CEL. This essay, then, has sought to invite our colleagues working in WIL to a moment of critical self-reckoning and to invite our CEL colleagues to engage these WIL efforts, as they occur on our campuses, with the tools of our CEL scholarship and practice. If CEL comes to be regarded as a particular form of WIL, as some expert panels and governmental bodies already regard it, then it is worth giving time and reflection to what distinctive insights it may have to offer. At worst, for CEL practitioners critical of WIL, this may appear simply to be making the best of a bad situation; however, as we have tried to illustrate in our third case study, it may also offer authentic opportunities for deeper reflection and transformed educational practice.

What is the purpose of engagement? The four authors of this study, trained in different disciplines, and teaching in vastly different programs, differ in our answers to this question. However, all of us share a commitment to rigorous self-inquiry as part and parcel of any educational endeavour. According to an emerging, professionalized model of WIL, one might see the placement site as one where students can gain experience in the skills and culture of a particular sector of the economy, or as an opportunity for them to apply what they already know to a workplace situation. Critical CEL asks students to do something more challenging: to reconsider what they consider knowledge, skills, and abilities to be in the first place. Perhaps we, as teachers in the contemporary academy, as citizens of wider professional and grassroots communities, and as participants in the broader conversation about the nature and purpose of higher education, may be well advised to do the same.

Engaged Scholar Journal: Community-Engaged Research, Teaching, and Learning 


\section{About the Authors}

Honor Brabazon is an assistant professor in the Centre for Criminology and Sociolegal Studies at the University of Toronto. She researches reconfigurations of political debate and dissent in the neoliberal period and is the editor of Neoliberal Legality: Understanding the Role of Law in the Neoliberal Project (2017).

Jennifer Esmail (corresponding author) is assistant director, Experiential Learning and Centre for Community Partnerships at the University of Toronto. Her areas of research include disability studies, animal studies, and community-university engagement. She is the author of Reading Victorian Deafness: Signs and Sounds in Victorian Literature and Culture (2013). Email: jennifer. esmail@utoronto.ca

Reid B. Locklin is associate professor of christianity and culture at Saint Michael's College and the Department for the Study of Religion, University of Toronto. His research touches on a variety of questions in Hindu-Christian studies and the scholarship of teaching and learning. He is the author or editor of five books, including the co-edited collections Teaching Civic Engagement (2016) and Comparative Theology in the Millennial Classroom (2016).

Ashley E. Stirling is associate professor, teaching stream, and vice-dean of Academic Affairs in the Faculty of Kinesiology and Physical Education, University of Toronto. Her areas of research include athlete maltreatment and positive athlete development in sport, as well as the scholarship of teaching and learning, specifically experiential and work-integrated learning. She recently co-authored the Higher Education Quality Council of Ontario publication "A Practical Guide for Work-Integrated Learning” (2016).

\section{References}

Anderson, J.R., Reder, L.M., \& Simon, H.A. (1996). Situated learning and education. Educational Researcher, 25(4), 5-11.

Ash, S.L., Clayton, P.H., \& Atkinson, M.P. (2005). Integrating reflection and assessment to capture and improve student learning. Michigan Journal of Community Service Learning, 11(2), 49-60.

Bach, S. (2012). Shrinking the state or the Big Society? Public service employment relations in an era of austerity. Industrial Relations Journal, 43(5), 399-415.

Billett, S. (1996). Towards a model of workplace learning: The learning curriculum. Studies in Continuing Education, 18(1), 43-58. 
Billett, S. (2002). Workplace pedagogic practices: Co-participation and learning. British Journal of Educational Studies, 50(4), 457-481.

Billett, S. (2009). Realising the educational worth of integrating work experiences in higher education. Studies in Higher Education, 34(7), 827-843.

Bosco, A., \& Ferns, S. (2014). Embedding authentic assessment in work-integrated learning curriculum. Asia Pacific Journal of Cooperative Education, 15(4), 281-290.

Brabazon, H. (2017). Introduction: Understanding Neoliberal Legality. In H. Brabazon (Ed.), Neoliberal Legality: Understanding the Role of Law in the Neoliberal Project (pp. 1-23). Abingdon, Oxon: Routledge.

Brackmann, S.M. (2015). Community engagement in a neoliberal paradigm. Journal of Higher Education Outreach and Engagement, 19(4), 115-146.

Bringle, R.G., \& Clayton, P.H. (2012). Civic Education Through Service- Learning: What, How and Why? In Mcllrath, L, Lyons, A., Munck R. (Eds.), Higher Education and Civic Engagement (pp. 101-124). New York: Palgrave Macmillan.

Bringle, R.G. \& Hatcher, J.A. (1995). A sevice-learning curriculum for faculty. Michigan Journal of Community Service-Learning, 2(1), 112-122.

Business/Higher Education Roundtable (BHER) (2016). Taking the Pulse of Work-integrated Learning in Canada. Retrieved from http://bher.ca/wp-content/uploads/2016/10/BHER-Academicareport-full.pdf

Butin, D. (2003). Of what use is it?: Multiple conceptualizations of service-learning in education. Teachers College Record, 105(9), 1674-1692.

Butin, D. (2005a). Preface: Disturbing Normalizations of Service-Learning. In D. Butin (Ed.), ServiceLearning in Higher Education: Critical Issues and Directions (pp. vii-xx). New York: Palgrave MacMillan.

Butin, D. (2005b). Service-Learning as Postmodern Pedagogy. In D. Butin (Ed.), Service-Learning in Higher Education: Critical Issues and Directions (pp. 89-104). New York: Palgrave MacMillan.

Butin, D. (2010). Service-Learning in Theory and Practice: The Future of Community Engagement in Higher Education. New York: Palgrave MacMillan.

Carniol, B. (1992). Structural social work: Maurice Moreau's challenge to social work practice. Journal of Progressive Human Services, 3(1), 1-20.

Clayton, P.H., \& Ash, S.L. (2004). Shifts in perspective: Capitalizing on the counter-normative nature of service-learning. Michigan Journal of Community Service Learning, 11, 59-70.

Clifford, J. (2017). Talking about service-learning: Product or process? Reciprocity or solidarity? Journal of Higher Education and Outreach, 21(4), 1-13.

Cress, C. (2011). Pedagogical and Epistemological Approaches to Service-Learning: Connecting Academic Content to Community Service. In C. Cress, D. Donahue, \& Associates (Eds.), Democratic Dilemmas of Teaching Service-Learning: Curricular Strategies for Success (43-54). Sterling, VA: Stylus.

Derris, K., \& Runions, E. (2016). More Than Global Citizenship: How Religious Studies Expands Participation in Global Communities. In F. Clingerman and R. Locklin (Eds.), Teaching Civic Engagement (pp. 184-204). Oxford and New York: Oxford University Press.

Dewey, J. (1938). Experience and Education. New York: MacMillan.

Dostilio, L.D. et al. (2012). Reciprocity: Saying what we mean and meaning what we say. Michigan Journal of Commuity Service-Learning, 19(1). 
Dunning, S. J., \& Artino, A. R. (2011). Situativity Theory: A Perspective on How Participants and the Environment Can Interact. Thousand Oaks: Sage.

Eyler, J. (2002). Reflection: Linking service and learning - Linking students and communities. Journal of Social Issues, 58(3), 517-534.

Eyler, J. \& Giles, D. (1999). Where's the Learning in Service-Learning? San Francisco: Jossey-Bass.

Furco, A. (1996). Service-Learning: A Balanced Approach to Experiential Education. Introduction to Service-Learning Toolkit. Washington, DC: Corporation for National Service.

Furco, A. (2010). The engaged campus: Toward a comprehensive approach to public engagement. British Journal of Educational Studies, 58(4), 375-390.

Giroux, H.A. (2014). Neoliberalism's War on Higher Education. Toronto: Between the Lines.

Hammersley, L.A. (2013). Community-based service learning: Partnerships of reciprocal exchange? Asia-Pacific Journal of Cooperative Education, 14(3), 171-184.

Hammersley, L.A. (2017). Language Matters: Reciprocity and its Multiple Meanings. In J. Sachs \& L.Clark (Eds.), Learning Through Community Engagement (pp. 115-131). Singapore: Springer.

Hatcher, J.A., \& Bringle, R.G. (1997). Reflection: Bridging the gap between service and learning. College Teaching, 45(4), 153-158.

Heldman, C. (2011). Solidarity, Not Charity: Issues of Privilege in Service-Learning. In C.Cress, D. Donahue \& Associates (Eds.), Democratic Dilemmas of Teaching Service-Learning: Curricular Strategies for Success (pp. 33-39). Sterling, VA: Stylus.

Howard, J.P.F. (1998). Academic service-learning: A counternormative pedagogy. New Directions for Teaching and Learning, 73, 21-29.

Jackson, D. (2016). Re-conceptualising graduate employability: The importance of pre-professional identity. Higher Education Research \& Development, 35(5), 925-939.

Jackson, D. (2017). Developing pre-professional identity in undergraduates through work-integrated learning. Higher Education, 74(5), 833-853.

Jacoby, B. (2014). Service-Learning Essentials: Questions, Answers and Lessons Learned. San Francisco: Jossey-Bass.

James, R.K. (2010). From 'slum clearance' to 'revitalisation': Planning, expertise and moral regulation in Toronto's Regent Park. Planning Perspectives, 25(1), 69-86.

Jameson, J.K., Clayton, P.H., \& Jaeger, A. (2010). Community-Engaged Scholarship as Mutually Transformative Partnerships. In L. Harter, J. Hamel-Lambert, \& J. Millesen (Eds.), Participatory Partnerships for Social Action and Research (pp. 259-277). Dubuque: Kendall Hunt.

Katz, M.B. (1993). Introduction: The Urban "Underclass" as a Metaphor of Social Transformation. In M. B. Katz (Ed.), The 'Underclass' Debate: Views from History. Princeton: Princeton University Press.

Kiely, R. (2004). A Chameleon with a Complex: Searching for Transformation in International Service Learning. Michigan Journal of Community Service Learning, 10(2), 5-20.

Kiely, R. (2005a). Transformative international service-learning. Academic Exchange, 9(1), 275-281.

Kiely, R. (2005b). A transformative learning model for service-learning: A longitudinal case study. Michigan Journal of Community Service Learning, 12(1), 5-22.

Kliewer, B.W. (2013). Why the Civic Engagement Movement cannot achieve democratic and justice aims. Michigan Journal of Community Service Learning, Spring 2013, 72-79.

Kolb, D.A. (1984). Experiential Learning: Experience as the Source of Learning and Development. Englewood Cliffs: Prentice Hall. 
Lakes, R. (2011). Work-ready testing: Education and employability in neoliberal times. Journal for Critical Education Policy Studies, 9(1), 318-340.

Larsen, M.A. (2015). International Service Learning: Engaging Host Communities - Introduction. In M.A. Larsen (Ed.), International Service Learning: Engaging Host Communities (pp. 3-18). New York and London: Routledge.

Lewis, O. (1975). Five Families: Mexican Case Studies in the Culture of Poverty. New York: Basic Books.

Locklin, R. (2010). Weakness, belonging, and the Intercordia Experience: The logic and limits of dissonance as a transformative learning tool. Teaching Theology \& Religion, 13(1), 3-14.

Locklin, R., \& Posman, E. (2016). Discourse, Democracy and the Many Faces of Civic Engagement: Four Guiding Objectives for the University Classroom. In F. Clingerman and R. Locklin (Eds.), Teaching Civic Engagement (pp. 3-22). Oxford and New York: Oxford University Press.

MacDonald, K., \& Vorstermans, J. (2015). Struggles for Mutuality: Conceptualizing Hosts as Participants in International Service Learning in Ghana. In M. A. Larsen (Ed.), International Service Learning: Engaging Host Communities (pp. 131-144). New York and London: Routledge.

Mezirow, J. (1991). Transformative Dimensions of Adult Learning. San Francisco: Jossey-Bass.

Mezirow, J. (2000). Learning to Think Like an Adult: Core Concepts of Transformation Theory. In J. Mezirow (Ed.), Learning as Transformation: Critical Perspectives on a Theory in Progress (pp. 3-34). San Francisco: Jossey-Bass.

Ministry of Advanced Education and Skills Development (2017). MAESD's guiding principles for experiential learning. Retrieved online from http://www.queensu.ca/ experientiallearninghub/sites/webpublish.queensu.ca.qelhwww/files/files/A04\%20EL\%20 -\%20Guiding\%20Priciples\%20FINAL\%20EN.pdf

Mitchell, T. (2008). Traditional vs. Critical Service-Learning: Engaging the Literature to Differentiate Two Models. Michigan Journal of Community Service Learning, Spring 2008, 50-65.

Morton, K., \& Bergbauer, S. (2015). A Case for Community: Starting with Relationships and Prioritizing Community as Method in Service-Learning. Michigan Journal of Community Service Learning, Fall 2015, 18-31.

Patrick, C.J., Peach, D., \& Pocknee, C. (2009). The WIL Report: Work-integrated Learning - A National Scoping Study. Brisbane: Queensland University of Technology Publications.

Perkins, H.A. (2009). Out from the (Green) shadow? Neoliberal hegemony through the market logic of shared urban environmental governance. Political Geography, 28, 395-405.

Pompa, L. (2002). Service-Learning as crucible: Reflections on immersion, context, power and transformation. Michigan Journal of Community Service Learning, 9(1), 67-76.

Premier's Expert Panel on the Highly Skilled Workforce (2016). Building the Workforce of Tomorrow: A Shared Responsibility. Toronto: Queen's Printer. Retrieved from https://www.ontario.ca/page/ building-workforce-tomorrow-shared-responsibility

Raddon, M., \& Harrison, B. (2015). Is service-learning the kind face of the neo-liberal university? Canadian Journal of Higher Education, 45(2), 134-153.

Sattler, P. (2011). Work-integrated learning in Ontario's postsecondary sector. Toronto: Higher Education Quality Council of Ontario.

Sinha, S. (2005). Neoliberalism and Civil Society: Project and Possibilities. In A. Saad-Filho and D. Johnston (Eds.), Neoliberalism: A Critical Reader (pp. 163-169). London: Pluto Press.

Slaughter, S.A., \& Rhoades, G. (2004). Academic Capitalism and the New Economy: Markets, State and Higher Education. Baltimore: Johns Hopkins. 
Stack, C.B. (1970). All Our Kin. New York: Basic Books.

Stanlick, S., \& Sell, M. (2016). Beyond superheroes and sidekicks: Empowerment, efficacy, and education in community partnerships. Michigan Journal of Community Service Learning, 23(1), 80-84.

Stirling, A., Kerr, G., Banwell, J., MacPherson, E., \& Heron, A. (2016). A Practical Guide for Work-integrated Learning. Toronto: HEQCO. Retrieved from http://www.heqco.ca/ SiteCollectionDocuments/HEQCO_WIL_Guide_ENG_ACC.pdf

Stoecker, R. (2016). Liberating Service-Learning and the Rest of Higher Education Civic Engagement. Philadelphia: Temple.

Toomey, A.H. (2009). Empowerment and disempowerment in community development practice: eight roles practitioners play. Community Development Journal, 46(2), 181-195.

University of Toronto (2017). Rethinking higher education curricula: Increasing impact through experiential, work-integrated and community-engaged learning. A white paper for the University of Toronto. Retrieved online from https://www.utsc.utoronto.ca/ctl/sites/ utsc.utoronto.ca.ctl/files/u8/UofT\%20White \%20Paper $\% 20$ Integrated $\% 20$ Learning $\% 20$ Experiences- $\% 20 J u n e \% 202017 \mathrm{a}-2 . p d f$

Vygotsky, L. (1978). Interaction between Learning and Development. In M. Gauvain \& M. Cole (Eds.), Readings on the Development of Children (pp. 34-40). New York: Scientific American Books.

Wacquant, L. (2001). Deadly symbiosis: When ghetto and prison meet and mesh. Punishment and Society, 3(1), 95-134.

Williams, A., Cloke, P., \& Thomas, S. (2012). Co-constituting neoliberalism: Faith-based organisations, co-option, and resistance in the UK. Environment and Planning, 44, 1479-1501.

Zemach-Bersin, T. (2007). Global citizenship and study abroad: It's all about US. Critical Literacy: Theories and Practices, 1(2), 16-28. 